\title{
Sterowanie rozwojem regionu przez nowoczesną architekturę, na przykładzie Rzeszowa oraz obszaru doliny lotniczej
}

\section{Controlling region's development through modern architecture on example} of Rzeszow and the airport area

\begin{abstract}
Streszczenie
Dynamiczny proces urbanizacji zmusza współczesnych urbanistów do całkowitego przeprojektowania mechanizmów planowania przestrzennego. Kreowanie jednostek wysoko wyspecjalizowanych technologicznie wydaje się być odpowiednim kierunkiem, umożliwiającym rozwiązanie problemów współczesnych miast. Województwo podkarpackie stanowi przykład tworzenia jednostki opierającej plany rozwoju na technologii lotniczej - 90 \% krajowej produkcji przemysłu lotniczego znajduje się w regionie. Sytuacja ta wygenerowała potrzebę stworzenia budynku lotniska oraz Centrum Wystawienniczo- Kongresowego w Jasionce, które przez swoją architekturę i rozwiązania technologiczne podniosą rangę oraz atrakcyjność regionu. Uczestnictwo w procesie projektowania umożliwiło wykonanie analiz urbanistycznych $\mathrm{i}$ architektonicznych badanego obszaru. Warto podkreślić, że zjawisko jest unikatowe w skali kraju, wymagające nieszablonowego podejścia wszystkich członków procesu projektowego.
\end{abstract}

\begin{abstract}
The dynamic urbanization process forces modern urbanists to completely redesign the spatial planning mechanisms. Creating highly specialized units seems to be the right direction to solve the problems of modern cities. Subcarpathian Voivodeship is an example of creating a unit based on development plans on aviation technology. $90 \%$ of domestic aviation industry is located in the region. This situation has generated the need to create an airport building and The Exhibition \& Congress Centre in Jasionka, which, through its architecture and technological solutions, will raise the profile and attractiveness of the region. Participation in the design process enabled urban and architectural analyzes of the area of research. It is worth stressing that the phenomenon is unique in the country, requiring the unconventional approach of all members of the design process.
\end{abstract}

Słowa kluczowe: Rzeszów, Dolina Lotnicza, Centrum Wystawienniczo- Kongresowe , lotnisko, planowanie przestrzenne, architektura Keywords: Rzeszów, Aviation Valley, The Exhibition \& Congress Centre, airport, spatial planning, architecture

Planowanie przestrzenne i architektura, w teorii korelacja jest oczywista, jednak praktyczne mechanizmy wzajemnego oddziaływania czynników twórczych nie w pełni wykorzystywane. Kontekst miejsca niejednokrotnie jest bagatelizowany, a projektowanie skupione jest przede wszystkim na kreowaniu nowoczesnej, zaskakującej formy. Rozpatrując fenomenalne przykłady architektury najnowszej można wysnuć wnioski, że były one tworzone w całkowitej symbiozie z otoczeniem, niejako „wyrastały z miejsca”, a powodzenie mogły osiągnąć jedynie w tej konkretnej lokalizacji. Efekt Bilbao ${ }^{1}$ ukazuje wielopłaszczyznowy sukces, który można uzyskać w wyniku kompilacji urbanistyki, kontekstu, kompozycji oraz odważnej
The correlation between spatial planning and architecture, in theory, is obvious but the practical mechanisms of interaction between creative factors are not fully utilized. The context of the place is often underestimated, and the design is focused primarily on the creation of a modern, surprising form. By examining the phenomenal examples of modern architecture one can conclude that they were created in total symbiosis with the environment, somehow "grew out of place" and that success could only be achieved in that particular location. The Bilbao's effect1 shows a multi-faceted success that can be achieved through the compilation of urbanism, context, composition, and coura- 
poprawiły prestiz portu. Powstanie tego dzieła architektoniczzacji regionu dla podróżujacych. Rzeszów staje się „południowo-wschodnim oknem na świat", jako najdalej wysunietym port na południowym-wschodzie w naszym kraju. Założeniem podstawowym wyboru tej lokalizacji była również budowa infrastruktury technicznej, skomunikowanie portu z miastem oraz skrócenie czasu podróży do minimum, poprzez autostradę oraz drogę ekspresową. Obecnie szacunkowy czas podróży z centrum Rzeszowa do strefy wynosi 20 minut.

Nowoczesny budynek Terminalu Pasażerskiego (il. 1) w Jasiono ma pozwolić na trzykrotne zwiekszenie liczby pasaze śm éć pozw

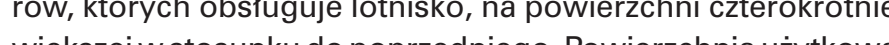
to psze w 14 tys. to ponad 14 tys. merow kwa i jow projact trzech nazien kych i jednej podziennej. Obiek zaprojektowany zostal na planie lltery T, z dwöch nakladających się na siebie bryt. Forma podstawowa, swym trzonem skierowanym na póthoc, tworzy elewacje frontową zorientowana w kierunku głównej drogi oraz strefy parkingów. Posiada ona dwa wejścia główne na elewacji północnej. Ten właśnie element można uznać jako najbardziej reprezentacyjny, poprzez interesującą formę stanowiąc przekrycie hali. Dach wykonany z blachy aluminiowej ma kształt łukowy, jakby unoszący się nad $w$ całosci przeszkloną podstawa. Wizualnie dobór materiałow potęguje wrażenie lekkosci, złudzenie unoszenia się. Forma jest niezwykle dynamiczna, posiadająca zaskakujące detale architektoniczne, z wyrożnieniem naroży, gdzie efekt jest znacznie spotęgowany (il. 2). Doszukać się można licznych porównań do czaszy spadochronu wznoszonego przez powietrze. Szersza część skierowana w stronę pasa startowego jest bardziej statyczna, już nie zaskakuje jedynie dopełnia całość gmachu. Jest niejako stabilizującym pionem całości, pełnią funkcje pasażerskie, techniczne oraz magazynowe (il. 3). Założenie zaprojektowane jest modułowo, w konstrukcii stalowego szkieletu ramowego uzupetnianego elementami żelotowymi Przyjete rozwiazanie pozwala aby w przyszłości mozliw by rozbura termina. Podstawowym atum budyku jest glówna ho tzarazem centrow hala izarazen centralsy tron in zlokalizwa con tralnie znajuje sie glówy ciąg schodow huchomych prowadzących na antrosolę. Na parterze znajdują się równiez trzy szyby windowe oraz kla pa ewaknacyjne. Po zachodniej stronie, nieco $w$ głębi znajduje się strefa odprawy pasażeSklepienie tworzy łukowata krzywizna dachu, odzwierciedlająca zewnętrzny ksztatt. Wykończone ono zostało drewnopodobnymi panelami w formie prostokątów o podwyższonych parametrach akustycznych, ze względu na specytikę budynku (il. 4). Spełniają one oprócz funkcji akustycznej, również ciekawy element aranżacji wnętrza. Na antresoli zaprojektowano częsć gastronomiczną , strefę kontroli bezpieczeństwa i kaplicę lotniskową. Strefę przedodlotową tworzą standardowe rozwiązania stosowane $\mathrm{w}$ tego typu budynkach, zawiera ona między innymi pomieszczenia komercyjne, poczekalnię, strefę kontrolną. Na drugim piętrze znajdują się dwa tarasy in 2012 significantly improved the prestige of the port. The emergence of this architectural work was a key premise of the plan for the modernization and esthetization of the region for travelers. Rzeszow becoming the "Soun East Whadow of the World" as the farthest south-eastern port in our country.
The basic premise of choosing this location was also the construction of technical infrastructure communication of the port with the city and the shortening of travel time to the minimum throug the motorway and the express road. Currently, the estimated travel time from the center of Rzeszow to the zone is 20 minutes.

The modern Passenger Terminal building in Jasion$k$ is to allow three times the number of passengers served by the airport, on an area four times larger sand square meters on four floors, three terrestria and one underground. The object was designed on a T plan, with two overlapping solids. The basic form, with its north-facing shaft, forms a fron elevation oriented towards the main road and car parks. It has two main entrances on the northern elevation. This element can be considered as the most representative, through an interesting form of covering the hall. The roof made of aluminum a fully glazed base. Visually, the if loating over terials intensifies the impression of lightness, the illusion of floating. The form is extremely dynamic with surprising architectural details, with distinctive corners, where the effect is greatly enhanced. One can find numerous comparisons to the parachute raised by the air. The wider part facing the runway is more static, it is no longer surprising just to fill the entire building. It is a stabilizing part of the whole, performing passenger, technical and warehous functions. The foundation is designed modularly, in the structure of a steel frame framework supple-
mented with reinforced concrete elements. The adopted solution allows for the future expansion of a still small terminal. The main asset of the building is the main hall and at the same time the central information and communication corridor, where the commercial cubicles are located. The main staircase leading to the mezzanine is centrally located. On the ground floor there are also three lift shafts and escape staircases. On the west side, there is a deep check-in area for passengers - a total of 17 arched curvature of the roof reflecting the outer shape. It was finished with wood-like panels in the form of rectangles with increased acoustic parameters, due to the specificity of the building. They fulfill the acoustic function, but are also an interesting element of interior design. On the mezzanine a gastronomy section, security control area and airport chapel were designed. The preflight zone forms the standard solutions used in this type of rooms, control zones. On the second floor therting two viewing terraces - inner and outer. The building is one of the most characteristic of the region distinguished by surprising elements. Its success is illustrated, despite a short period of operation, by

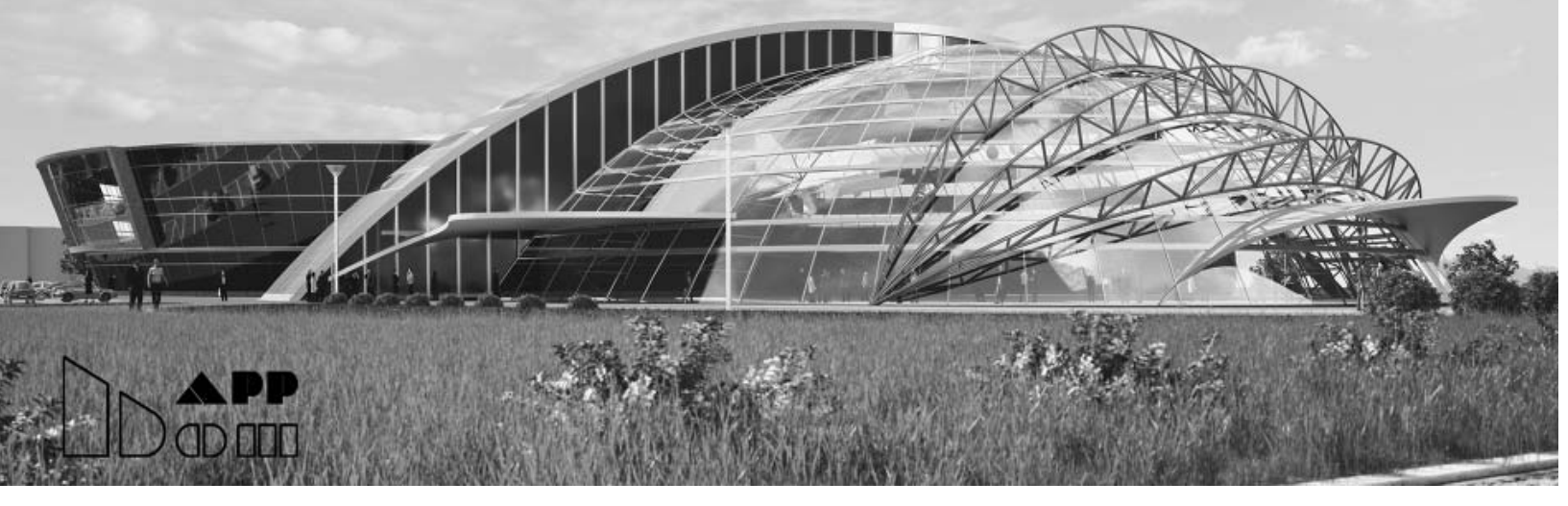

1. 5. Budynek Centrum Wystawienniczo- Kongresowego (wizualizacja APP DOM) / The Exhibition \& Congress Centre (DOM Design Studio visu-

widokowe - wewnętrzny i zewnętrzny. Budynek jest jednym $z$ najbardziej charakterystycznych regionie, wyróżnia się zaskakującymi elementami. Sukces obrazuje zajęcie, pomimo krótkiego okresu funkcjonowania, w 2016 roku 24 miejsca w zestawieniu Best Airports in Europe 2016, przygotowane na podstawie badań zadowolenia pasażerów.

Kolejnym etapem towarzyszącym dynamicznemu postępoKi Doliny Loticze byla budowa Cenamiczemu postępo- Don -Kongresowego, zlokalizowanego na przeciwko budynku Terminalu (Il. 5). W zalożeniu zespolu projektowego Autorskiej Pracowni Projektowej DOM mialo ono skupiac myśl technologiczną oraz naukową tego specyficznego, ogromnie interesującego osfocka. Stanowic przestzen atrakcyjną dla inwestorów z całego swiata jak i naukowcow, przez organizację wszelakich targów, kongresów oraz wydarzen naukowych. Teren przeznaczony na inwestycję byl niezwykle wymagajacy ze względu na malą powierzchnię. Aby spelnic wymog ochrony przeciwpozarowej, możliwości odpowiedniego zagospodarowania otoczenia i wyposażenia w małą architekturę zostały mocno ograniczone. Forma nieco futurystyczna miała sprostac wymogom tego intensywnie rozwijajacego się obszaru, tworzyć przestrzeń kreatywną, ciekawa i stymulującą użytkowników, nietracącą na aktualności. Powierzchnia użytkowa budynku wynosi ponad 27 tysięcy metrów kwadratowych, na czterech kondygnacjach. Bryła budynku składa się z dwóch cześci, które obrazują podział funkcji. Przeszklon kopuła w kształcie elipsy, znajdujaca sie po stronie wszhodniej tworzy cześć wystawiennicza. Usytuowanie jej na parterze z mozli cró́c bys bó per liwościa prezentowania eksponatów czy urzadzeń możKopu w czésci frontowej jest cat-

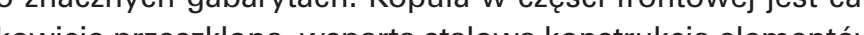

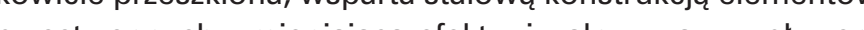
d in Take rozwizanie insprowane bylo niebosk unem, podnia. Takie rozwiazznie inspirowane było nieboskłonem, potrzebą "otwarcia" budynku na otoczenie, popisem możliwości inzynierskich i technologicznych (il. 6). Glowną cechą budynku, tak ściśle związanego z lotnictwem, według głównego architekta Henryka Sobolewskiego, musiała być transparentność, możliwoscc korelacji wnętrza z zewnętrzem. Umożliwi to organizację pokazów samolotowych, jako towarzyszących wydarzeniom organizowanym w CWK, otoczenie przenika sie ze środkiem dając dodatkowe wrażenia estetyczne. Hala zosta- winning, in 2016, 24th place in the Best Airports in Europe 2016, based on passenger satisfaction surveys.

Another stage accompanying the dynamic progion of The Aeronautical Valley was the construcopposite the Terminal building. In the premise of the design team of the DOM Design Studio it was supposed to focus on the technological and scientific thought of this specific and very interesting from all over the world as well as scientists, by organizing trade fairs, congresses and scientific events. The area of the investment was extremely demanding due to its small size. Meeting the requirements of fire protection, the ability to properly manage the environment and equipment in small architecture was severely limited. The form was a bit futuristic to meet the requirements of this intensively developing area, to create a creative, ip to date. thousand square meters, on four floors. The building block consists of two parts, which illustrate the division of functions. The glazed elliptical dome located on the east side, forms an exhibition area. Its location on the ground floor with the possibility of direct access from the ground level what was caused by the practical purpose and the possibility of presenting exhibits or devices and models of considerable dimensions. The dome in the front ing spatial elements changing the visul effect with the passing of the day. Such a solution was inspired by the sky, the need to "open" the building to the surroundings, showcasing the engineering and technological possibilities. The main feature of the building, so closely related to aviation, according to the chief architect Henryk Sobolewsk, had to be transparency, the ability to correlate the interior with the outside. This enables the organization of airplane shows, as accompanying events (a) hall has been divided vertically by two levels of terraces at a height of more than four and eight meters; those levels allow viewing the exhibits from different perspectives, giving the possibility of approaching, almost touching the suspended 

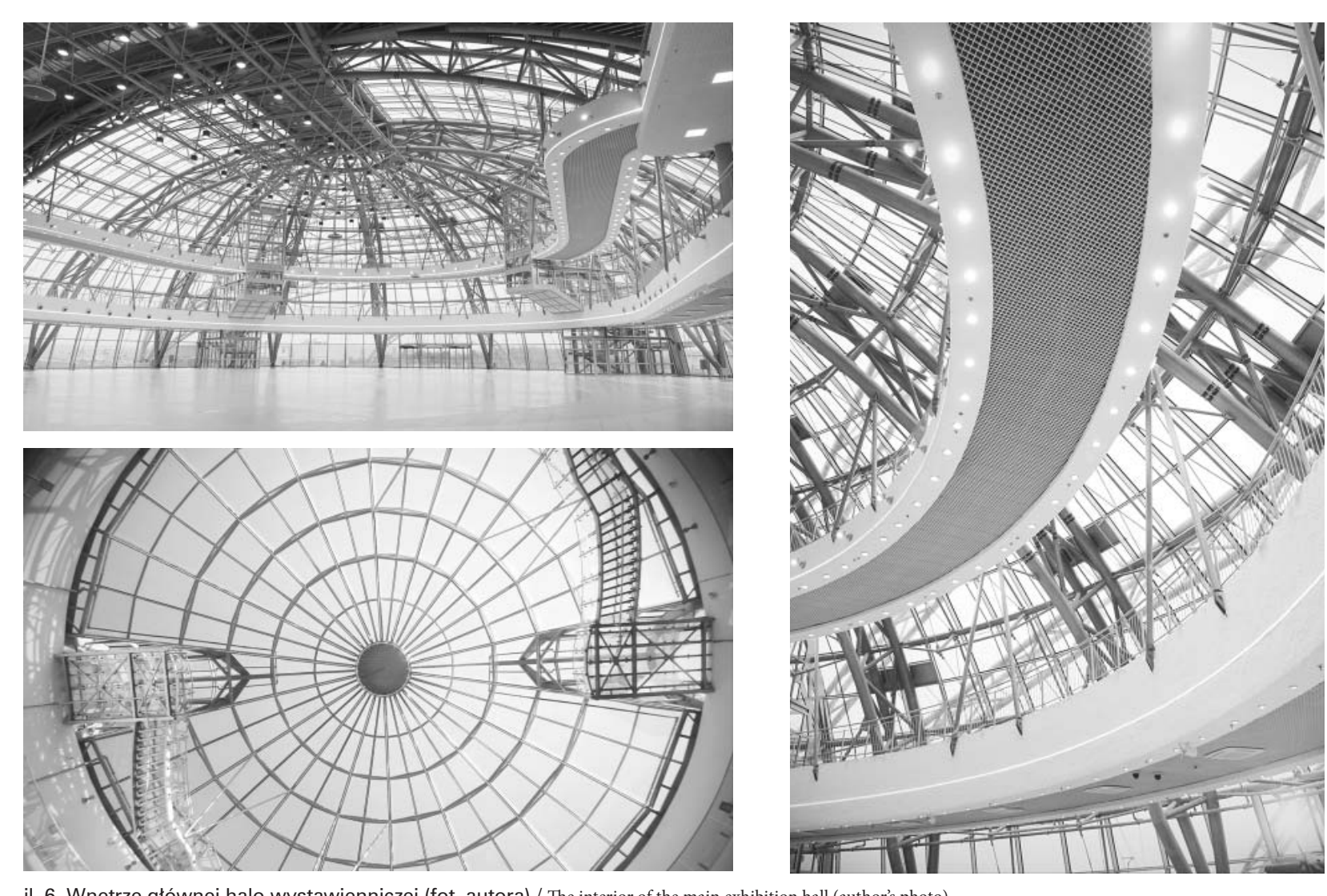

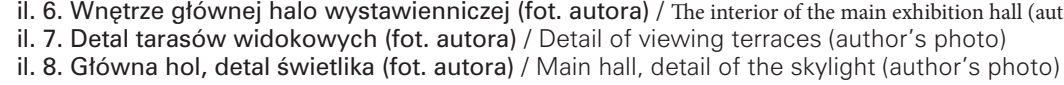

ła podzielona w pionie dwoma poziomami tarasów na wysokości ponad czterech i ośmiu metrów, płaszczyzny pozwalają na oglądanie wystaw z różnej perspektywy, daja możliwość zbliżenia sie, prawie dotknięcia podwieszonych elementów (il. 7). Mogą one również służyć jako dodatkowa powierzchnia wystawiennicza, stanowiska dziennikarskie lub gabinety rozmów i negociai. Druga bryte tworzy sal kongresabinety rozmów i negoci po 870 osób, dizy sala kongresowa mogaca pomiesci pon mnies mniejszych (20-60

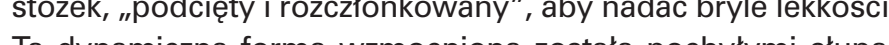
Ta dy na kicza for mi konstrkeyny przeciwwage dla statycznej częsci wystawienniczej. Na płynnym przecięciu się tych dwóch form, po stronie południowej, zlokalizowano glowne wejscie do budynku, prowadzące do przestronnego holu, centrum gmachu, będącym również głównym punktem informacyjnym i komunikacyjnym. Zlokalizowane zostało tutaj zaplecze techniczne oraz pomieszczenia jak szatnie, restauracja, sala bankietowa, ciągi komunikacyjne. W formie miało nawiązywać do wielopoziomowego ronda, doświetlonego szklanym świetikiem w centralnym punkcie (il. 8). I tutaj działa zasada "otwarcia" przestrzeni na otoczenie - niebo. Wokół niego na najwyższym piętrze znajduje się taras widokowy, z którego rozciąga się widok na całą strefę.

Budynek posiadający składowe, odzwierciedlające funkcje wewnętrzna, ktore może wyodrębnic i wskazac kazdy obserrooms. The second body creates a congress hal capable of accommodating over 870 people, two smaller conference rooms for two hundred and twenty people and one hundred ninety people and cone, "cut and split" to give a light impression. This dynamic form was reinforced with slopin construction columns, giving the impression. It is a counterweight to the static part of the exhibition. At the intersection of these two forms on the south side, the main entrance to the building leads to the spacious lobby, the center of the building, which is also the main information and communication point. There are technical facilities and rooms such as locker rooms, restaurant, banquet hall, coma multi-level roundabout, illuminated by a glass skylight at a central point. And here is the principle sky. Around it on the top floor is a viewing terrace, which overlooks the whole area.

A building with components that reflect an internal function that can be identified and identified by each observer has a common denominator-transparency. It allows one to observe the surrounding, idea of place and region, additionally mobilizes the mind. The technical facilities of the building together with the car park are designed on the un- elements. They can also serve as extra exhibition of "opening" the space to the surroundings - the wator, posiada wspólny mianownik -transparentnośc. Pozwatów, niejako ukazując idee miejsca oraz regionu, dodatkowo mobilizuje umysł. Zaplecze techniczne budynku wraz z parkingiem zaprojektowane zostało na kondygnacji podziemne Oficjalne otwarcie nastapiło 23 czerwca 2016 roku, realnie skutki stworzenia tego obiektu będziemy mogli obserwowac na przestrzeni lat Obecnie budynek do swoich sukcesów może zaliczyć organizacje Kongresu 590, czy Europejskego Kongresu Robotycznego oraz Zawodd kich Cieszy sie za

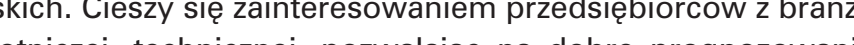
jak i samym miastem.

Jak isamy na okreslic jako jeden z najatrakcyjniejszych terenów przeznaczonych pod inwestycję przemysłu lotniczego. Pierwsz znaczące kroki do wytworzenia $w$ tym regionie mocnego, dynamicznie rozwijającego się ośrodka zostaly poczynione. Powstala wysokje kasy architektura oraz infrastruktura, dzięki której obszar stał się wyjątkowo atrakcyjny. Wieloletnia modernizacja, stopniowe wdrażanie założeń i ich ciągła modyfikacja aby sprostac wymaganiom najnowocześniejszych technologii, pozwala zapany podmiejskich. Rezultat będzie można obserwować na przestrzeni lat, szacuje się ciągly wzrost liczby pasazerow korzystających z infrastruktury lotniczej na Podkarpaciu, jak również zauważa znaczne zainteresowanie inwestycyjne $i$ jego ciagłły wzrost. Centrum Wystawienniczo- Kongresowe stało się wizytówką regionu, podnoszącą jego konkurencyjność. Omawian budynki stały się przyczyną pozytywnego ożywienia, aktywizacji, czego skutki będą odczuwalne $w$ formie niewymierne jak estetyzacja przestrzeni, modernizacja infrastruktury $\mathrm{i}$ je rozbudowa, jak również wymiernej przez wzrost gospodarczy, nowe miejsca pracy, podwyższenie jakości życia mieszkańców regionu Proces sterowania", kierunkowania rozwojuncó rom dynku. Nie można wyznaczyć ścistych ram poczatku i końca, chero odpowiednie zarzadzanie w skali pegionalnej, krajowej, a naw ǵm Zniajy pozwa na osiagniécie zadowalaja-

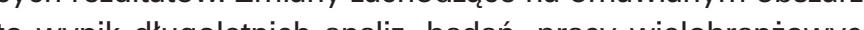

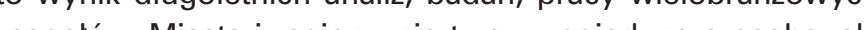
grupolow. Mista i regionu nie tworzy pojedyncza osoba, ale grupa zmieniająca się w czasie, odpowiadająca na trudności powstale $w$ obecnym dla niej momencie, ale i przewidująca pewne aspekty, zmienne, na które będzie konieczna odpowiedź w przyszłossci. Urbaniści, naukowcy i projektanci staja przed koniecznoscią zredefiniowania wzorcow powstałych $n$ przestrzeni wiekow, jako niejednokrotnie nieaktualnych. Próby, niekiedy eksperymenty, nowatorskiego komponowania założen urbanistycznych przez formę architektoniczna, mają na celu sprostac potrzebom coraz bardziej rozrastajacych się aglomeracji. Tworzenie wysoko wyspecjalizowanych ośrodkow, zmusza podporządkowanie struktur miejskich tym właśnie funkcjom. Korelacja dzieła architektonicznego i kompozycji tkanki miejskie, założenia urbanistycznego, pozwal sterować rozwojem całego załozenia. Tworzenie w skali ma- derground floor. The official opening took place on June 23, 2016, however the real effects of the creation of this work will be able to observe over the years. Today, to the building's success can be counted organizing events such as the 590 Contial Arts Mars. It gains the interest of aerospace industry technicians, allowing good forecasting and further control of the development of suburban areas of Rzeszow and the city itself. AEROPOLIS The Podkarpackie Science and Technology Park can be described as one of the most attractive areas for the aviation industry. The first significant steps to create a strong, dynamically developing center in this region have been made. High-end architecture and infrastructure have made his area extremely plementive. Long-term modernization, gradual in modification to meet the demands of state-of-theart technology, allow to control the uncontrolled urbanization of suburban areas. The result will be visible over the years, a steady increase in the number of passengers using aviation infrastructure in the Podkarpacie region is estimated, as well as a noticeable interest in investment and its continued growth. The Exhibition \& Congress Centre its bempetitiveness. These buildings haveasing the cause of a positive revival, with the impact of which will be felt in an immeasurable form such as the aesthetizing of space, the modernization of infrastructure and its expansion as well as the measurable through growth, new jobs and the quality of life of the region's inhabitants. The process of "steering", direction of development through ar chitecture does not end on the solemn opening of the building. It is not possible to set a strict staf and even alobal governance can achieve nationa tory results. The changes taking place in this area are the results of long-term analyzes, researches and work of many teams. Cities and regions are not created by a single person, but a group that changes over time, responding to the difficulties that arise at the moment, but with certain aspects, variables that will need to be answered in the future. Urban planners, scientists and designers ace the need to redefine patterns that have been Attempts sometimes experiments, innoted composition of urban planning through architectural form, are aimed at meeting the needs of increasingly growing agglomerations. The creation of highly specialized centers forces the subordination of urban structures to these functions. Correlation of architectural work and composition of urban layers, urban planning, allows to contro the development of the whole premise. Macroscaling, unweighting the centre, and positioning can improve the performance of both zones. Th image of a contemporary city as a chaotic, diso-derly, decomposed, factor allows to understand the complexity between the individual elements. The paths, junctions, points, areas, and edges in 
kro, odciążające ośrodek centralny oraz lokujące poszczególne funkcje poza głównym trzonem, może poprawić funkcjonowanie obu stref. Wizerunek miasta współczesnego jako chaotycznego, nieuporządkowanego, rozłożony na czynniki, pozwala na zrozumienie złożoności pomiędzy poszczególnymi elementami. Drogi, węzły, punkty, obszary i krawędzie w które przedstawia nam w swojej teorii Kevin Lynch ${ }^{6}$ zaczynają komponować się w nową, aktualną całość. Każdy przypadek jest unikatowy, znajdując analogię twórca może kreować i stymulować rozwój poszczególnych składowych. Niemożliwa jest adaptacja rozwiązania nieprzystosowanego do konkretnych warunków, gdyż istnieje niebezpieczeństwo powstania karykatury pierwowzoru. Proces może osiągnąć sukces w przypadku połączenia racjonalnego planowania przestrzennego, architektury wykraczającej poza współcześnie wyznaczone ramy, odpowiednio przygotowanych mechanizmów administracyjno-ekonomicznych oraz często pomijanego aspektu społecznego. Uświadamianie i aktywizacja osób uczestniczących, użytkowników danej przestrzeni stanowi ogromny potencjał, ponieważ rozwój należy również rozumieć poprzez wzrost społeczny. Wysoko wykwalifikowane kadry podnoszące swoje kompetencję będą również „podnosiły” jakość przestrzeni, będąc katalizatorem kolejnych modyfikacji w tkance miejskiej. Sceptycy takich procesów pomijają, według autorki, właśnie ten ostatni poruszony aspekt całego procesu. Przemiany współczesnych miast należy rozpatrywać jako wielopłaszczyznowy proces gospodarczo-społeczno-architektoniczny.

Obecna sytuacja jest ekscytująca, bowiem możemy tylko prognozować oraz marzyć, ponieważ nie znamy przyszłości. Zmierzamy w nieznane ale mam nadzieję, że optymistycznie ${ }^{7}$.

\section{PRZYPISY:}

1 Efekt Bilbao pojęcie jest wynikiem fenomenalnego procesu rewitalizacji hiszpańskiego miasta Bilbao. Miasto jako ważny ośrodek przemysłowy XX wieku, poprzez upadek zakładów metalurgicznych i stoczni stracił na prestiżu. Zapobiegając dalszej degradacji zrealizowano tam kompleksowy projekt odnowy wizerunku przestrzeni miejskiej, którego podstawą była architektura kreowana przez najlepsze jednostki projektowe ze świata. Muzeum Guggenheima autorstwa Franka Gehery'ego stało się symbolem przedsięwzięcia o wieloaspektowym znaczeniu kulturowym, ekonomicznym, społecznym.

2 Obszar funkcjonalny według Koncepcji Przestrzennego Zagospodarowania Kraju 2030 określony jest jako „zwarty układ przestrzenny składający się z funkcjonalnie powiązanych terenów, charakteryzujących się wspólnymi uwarunkowaniami".

${ }^{3}$ ROF - Rzeszowski Obszar Funkcjonalny

${ }_{4}^{4}$ Podkarpacki Park Naukowo- Technologiczny AREOPOLIS - 19 maja 2003 roku zostaje podpisane porozumienie o utworzeniu Parku, a w lipcu 2004 roku Samorząd Województwa Podkarpackiego podjął uchwałę o realizacji projektu (Uchwała Sejmiku Województwa Podkarpackiego nr XXVV273/04).

${ }^{5}$ R. Bereś, Nowa Wieś, RS DRUK Drukarnia Wydawnictwo, Trzebownisko 2013, str. 35

${ }^{6}$ K. Lynch, Obraz Miasta, Wydawnictwo Archiwolta Michał Stępień, Kraków 2011 7 W. Seruga, ... O architekturze mieszkaniowej XXI wieku - uwag kilka, Środowisko Mieszkaniowe 15/2015, Politechnika Krakowska, Kraków 2015

\section{LITERATURA}

Bereś R., Nowa Wieś, RS DRUK Drukarnia Wydawnictwo, Trzebownisko 2013 Kowicki M., Wieś przyszłości jako alternatywa osadnicza miasta, Politechnika Krakowska im. Tadeusza Kościuszki, Kraków 1997

Lynch K., Obraz Miasta, Wydawnictwo Archiwolta Michał Stępień, Kraków 2011 Obszary atrakcyjności inwestycyjnej Województwa Podkarpackiego, strona Podkarpackiego Biura Planowania Przestrzennego, www.pbpp.pl/opracowania (10.04.2017)

Obszary funkcjonalne w Województwie Podkarpackim, strona Podkarpackiego Biura Planowania Przestrzennego, www.pbpp.pl/opracowania (10.04.2017)

Seruga W., ... O architekturze mieszkaniowej XXI wieku - uwag kilka, Środowisko Mieszkaniowe 15/2015, Politechnika Krakowska, Kraków 2015
Kevin Lynch's theory6 start composing into a new, current whole. Each case is unique, by finding an analogy the creator can create and stimulate the development of individual components. It is impossible to adapt a solution not adapted to specific conditions, as there is a risk of caricature of the prototype. The process can be successful in case of combination of rational spatial planning, architecture beyond the currently defined framework, adequately prepared administrative and economic mechanisms, and often overlooked social aspects. The awareness and activation of the participants, users of a given space is a huge potential, as development must also be understood through social growth. Highly skilled staff upgrading their competence will also "raise" the quality of space as a catalyst for further modifications in urban tissue. The skeptics of such processes tend to omit, according to the author, just this last touched aspect of the whole process. The transformation of modern cities should be seen as a multifaceted economic, socio-architectural process.

The current situation is truly exciting because all we can do is forecst and dream; we do not know the future and the societies of the future. We are heading for the unknow, but I do hope that we are doing it with optimism?

\section{ENDNOTES}

1 The Bilbao's effect is the result of the phenomenal revitalization process of the Spanish city of Bilbao. The city was an important industrial center of the twentieth century, but by the fall of metallurgical plants and shipyards lost its prestige. To prevent further degradation, there was a project of complete renovation of urban space, based on the architecture created by the best design units in the world. Frank Gehery's Guggenheim Museum has become a symbol of the venture with multifaceted meaning - cultural, economic, social.

2 The functional area according to the Concept of Spatial Land Development 2030 is defined as "a compact spatial layout consisting of functionally linked areas, characterized by common conditions".

${ }^{3}$ Rzeszów Functional Area (In Polish ROF - Rzeszowski Obszar Funkcjonowania)

${ }_{4}^{4}$ On May 19, 2003, an agreement was signed on the establishment of the Park, and in July 2004, the Podkarpacie Region Self-Government passed a resolution on the implementation of the project (Resolution of the Sub-Parliament of the Podkarpacie Region No. XXVV273 / 04)

${ }^{5}$ R. Bereś, Nowa Wieś, RS DRUK Drukarnia Wydawnictwo, Trzebownisko 2013, page 35

${ }^{6}$ K. Lynch, Obraz Miasta, Wydawnictwo Archiwolta Michał Stępień, Krakow 2011

7 W. Seruga, ... Some Comments on the $21^{*}$ st-century Residential Architecture, Housing Environment 15/2015, Politechnika Krakowska, Krakow 2015

\section{BIBLIOGRAPHY:}

Bereś R., Nowa Wieś, RS DRUK Drukarnia Wydawnictwo, Trzebownisko 2013

Kowicki M., Wieś przyszłości jako alternatywa osadnicza miasta, Politechnika Krakowska im. Tadeusza Kościuszki, Kraków 1997

Lynch K., Obraz Miasta, Wydawnictwo Archiwolta Michał Stępień, Krakow 2011

Obszary atrakcyjności inwestycyjnej Województwa Podkarpackiego, retrieved at: www.pbpp.pl/opracowania (10.04.2017)

Obszary funkcjonalne w Województwie Podkarpackim, retrieved at: www.pbpp.pl/opracowania (10.04.2017)

W. Seruga, ... Some Comments on the 21*st-century Residential Architecture, Housing Environment 15/2015, Politechnika Krakowska, Krakow 2015 